\title{
Taxonomic revision of Melilotus indicus complex in Egypt
}

\author{
Faiza A. Shehata
}

Botany\& Microbiology Department, Faculty of Science, Menoufia University

Corresponding author: faizashehata@yahoo.com

\begin{abstract}
Macro- and microomorphological features of Melilotus indicus complex in Egypt were examined using light and scanning electron microscopy, these includes embryo and seed characters, anatomical structure of stem and seed spermoderm. In the present study, three varieties were recorded: var. indicus, var. bonplandii and var. tommasinii. of which var. indicus is a new record to the flora of Egypt. The study revealed that morphological, anatomical and seed characters are of taxonomic significance. A key for identification of the varieties was also given.
\end{abstract}

Keywords: anatomy, Melilotus indicus, morphology, seed morphology, spermoderm

\section{Introduction}

Fabaceae Lindl. is the third largest family of flowering plants with about 751 genera and 19500 species (Christenhusz and Byng 2016), distributed mainly in the temperate and subtropical parts of the world. Many of the species are of economic importance as the source of food, fixation of atmospheric nitrogen etc. (Mirzaei et al. 2015). The genus Melilotus L. (subfamily Papilionoideae, tribe Trifolieae), is represented by 24 species with a worldwide distribution growing usually in the calcareous soil regions distributed in Central and Eastern Europe, the Mediterranean countries, Asia and North America (Hoppe 1975).

There are few studies concerning the morphology, anatomy, pollen and seed morphology of Melilotus. Mcmurry \& Fisk (1936) studied the vascular anatomy of $M$. albus. Özbek et al. (2014) investigated morphological, anatomical, pollen and seed morphological properties of Melilotus bicolor endemic to Turkey; while Gupta (1977) investigated the vascular anatomy of the Melilotus flower. Abid et al. (2018) investigated seed characters and chemotaxonomy of four species of Melilotus from Pakistan including $M$. indicus. Gazara et al. (2001) described the morphological characters of three genera: Trifolium L., Trigonella L. and Melilotus L. of the tribe Trifolieae in order to construct their phylogenetic relationships. Taia (2004) studied seed characters in 38 species of tribe Trifolieae, which showed that Melilotus have different seed shape and ornamentations, which can be used in the identification of the species. Lashin (2006) investigated the pollen grains of nine taxa belonging to five genera of the tribe Trifolieae of subfamily Papilionoideae from Egypt including Melilotus indicus to evaluate the comparative morphology of the pollen in the tribe. The seedling of Leguminosae was discussed by Duke \& Polhill (1981), they claimed that the combination of seed and adult features represented on seedlings may provide numerous clues for field. Various works have shown that the microcharacters of seed coat, anatomical features and pollen grain features in Leguminosae can be used as diagnostic characters at generic, specific and even at infraspecific levels. Seed morphology and structure in the Leguminosae has been the base of numerous studies (Gunn, 1972; Ignacimuthu \& Babu, 1985; Abd El- Gawad et al. (1989); Hosni \& Karemy 1993, Abou-ElEnain \& Loutfy 1999, El Karemy \& Hosni 1999, Abou-El-Enain et al. 2007; Nyola \& Sharma, 2009; Özbek et al. 2014; Zareh et al. 2017; Khandani et al. 2016; Abid et al. 2018)

In Egypt Melilotus is represented by seven species (El-Hadidi \& Fayed 1994/95; Boulos 1995, 1999, 2009), while Täckholm (1974) recorded only six species of Melilotus. She recorded two varieties within the multiform species $M$. indicus namely: var. tommasinii Jord. and var. bonplandii Ten. The present study aims to revise Melilotus indicus complex in Egypt with special reference to 


\section{Taxonomic revision of Melilotus indicus complex in Egypt}

macromorhological and anatomical features as well as embryo and seed structure that hoped to be reliable for the distinction of different varieties; described their distribution and habitat in Egypt along with its morphological, palynology, seed, embryo and anatomical characters.

\section{Materials and Methods}

The present study based on fresh materials collected from various regions in Egypt, in addition to herbarium specimens deposited in Menoufia University Herbarium (Acronym MNF). The specimens were identified using various books of Flora (Täckholm 1974, Boulos 1999).

For Macromorphological Studies of embryo: mature seeds were soaked in tap water over night; testa was removed then examined using stereomicroscope then photographed using Zeiss research microscope.

For the Anatomical Studies: samples for anatomy of stem were chosen from both herbarium and fresh material. All assessments were made on all plants at similar developmental stages (fruiting stages) and in comparable positions of each plant. Stem samples were taken from $4^{\text {th }}$ internodes from the apex about 2-3 cm. Fresh materials were fixed in F.A.A. (5:5:90), while dried herbarium specimens of stem and leaves were first softened by either normal or warm water, after fixation stem and leaves specimens were transformed in ethyl alcohol series, then embedded in paraffin wax. The specimens were sectioned at $10-15 \mu \mathrm{m}$; sections were dehydrated in alcohol-xylol series. Sections were stained in safranin and light green according to Sass (1961). The transverse sections of stem and leaves were examined by using light microscope. A Planimeter was used for estimation of each tissue in the section area. Terminology followed Abd El-Rahman et al. (1976); Pandy (1982) and Barthlott (1981).
For the study of seeds: at least 20 seeds from different individuals were examined by Light microscope (LM) to assess morphological characters and general features of the spermoderm. For SEM microscopy, seeds were mounted on brass stubs and coated with a thin layer of gold and examined using JEOL JSM 530P SEM at Electron Microscopic Unit, Faculty of Science, Alexandria University. For anatomical investigation of seeds, the seeds were soaked in water for 12 hrs, embedded in paraffin wax, microtomed at 12$15 \mu \mathrm{m}$, dehydrated and stained with safranin according to conventional method of Johansen 1940). Terminology followed Corner (1976), Lersten (1981), Barthlott (1981, 1984), Stearn (1992), Werker (1997) and Norbert \& Jonitz (2009).

The results were summarized in Tables (1-4) showing the variation between the studied varieties. Photographed obtained were shown in Figures (I-IV).

\section{Results and Discussion}

According to Schulz (1901), Melilotus indicus has three varieties, var. indicus, var. tommasinii and var. bonplandii; while Morton (1915) recorded only two varieties: var. indicus and var. tommasinii. Täckholm (1974) reported two varieties from Egypt: var. tommasinii and var. bonplandii based on plant size, number of flowers, legume length while El Hadidi\& Fayed (1994/95) and Boulos (1999, 2000 \& 2009) recorded the species without infraspecific taxa. No comprehensive studies on Melilotus indicus in Egypt had been done before, only few studies were done among the revision of some other taxa (e.g. Taia 2004, Gazara 2001, Lashin 2006). In the present study three varieties were recognized within $M$. indicus based on Macromorphological characters (habit of stem, hairs and midrib colour, flower characters) as well as embryo characters; radical shape, anatomical features of stem (epidermal and collenchyma cell shape, number of vascular bundles) and seed coat pattern (curvature of outer periclinal wall) which confirmed the 


\section{Faiza A. Shehata}

morphological results to great extent and agreed with Schulz's concept (1901). Our results, however, revealed that such characteristics can play a determining role in differentiating between different varieties and distinguishing them from one another. The varieties of $M$. indicus in Egypt can be distinguished according to the following key:

1a-Plant erect, radical in embryo cylindrical, collenchyma cell shape radially elongated, seed coat pattern rugose-tuberculate in between. .var. indicus 1b-Plant procumbent, radical in embryo ovate, collenchyma cell shape isodiametric-tangentially elongated, seed coat pattern verrucate with irregular surface ................................ 2 2a- Leaves with red vein (midrib), number of flowers up to 25, standard with obtuse apex, ovary elliptic, number of vascular bundles 13-14, Curvature of outer periclinal wall convex ..var. bonplandii

2b- Leaves with colorless vein (midrib), number of flowers 30-35, standard with emarginated apex, ovary oblong, number of vascular bundles 18-20, curvature of outer periclinal wall concave.

var. tommasinii

\section{Taxonomy and morphological studies} (Table 1).

Melilotus indicus (L.) All. Fl. Pedem. 1:308(1785) var. indicus.

Basionym: Trifolium melilotus- indica L.Sp.Pl.ed.1:765(1753).

Annual herb, up to $30 \mathrm{~cm}$ height, stem erect, hairy, branched from base, lower branches cylindrical with protrudes, upper branches angular, internodes 2-3.5 cm long. Leaves 2.5-4(5) cm long, petiolate, petiole 0.81.5(2) cm long, lamina 12-18(20) x4-6mm, elliptic, sparsely hairy, serrate-ciliate margins, and acute apex. Stipules 6-8x2-3mm, ovate, entire margin, acute-acuminate apex. Inflorescence raceme, 1.2-1.5 cm long, shorter than the bract, 25-30 flower; flowers sessilesubsessile, 1.8-2 mm long; calyx hairy, 1.2$1.5 \mathrm{~mm}$ long, connate with teeth, tube 0.8-1 $\mathrm{mm}$ long, longer than teeth, teeth $0.4-0.5 \mathrm{~mm}$ long; petals yellow, standard 1.8-2x0.8-1 mm, longer than wings and keels, standards lamina elliptic with emarginate apex; wings as long as keels or slightly shorter, wings $1.6-1.8 \mathrm{~mm}$ long with obtuse apex, lamina 1-1.2 mm long, claw 0.4-0.6 mm long; keels 1.8-2 mm long with acute-obtuse apex, lamina 1.4-1.6 mm long, claw 0.4-0.6 mm long. Stamens diadelphous, 1.6-1.8 $\mathrm{mm}$ long, free filaments 0.8-1 mm long, anther ovate- oblong, $0.6 \times 0.8$ mm long. Carpel one,1.6-1.8 mm long, ovary 0.8-1 mm long, ovoid, papillate, style 0.6-0.8 $\mathrm{mm}$ long, stigma up to $0.2 \mathrm{~mm}$ long, ovate. Pod globose with reticulate ridges and acute apex, 3-3.24x1.8-2mm, indehiscent, 1-2 seeded. Seeds ovoid, yellow- brown.

Melilotus indicus (L.) All. var. bonplandii (Ten.) O. E. Schulz, Bot. Jahrb. Syst. 29:715. (1901)

Basionym: Melilotus bonplandii Ten., Index Sem. Hort. Neapol. 1833:14(1833)

$M$. indicus var. bonplandii differ from var. indicus in stem being cylindrical in lower part and cylindrical with ridges in upper part. Flowers 30-35. Calyx 1.8-2 mm long, petal 2.8-3.5 mm long. Stamens up to $2.5 \mathrm{~mm}$ long. Carpel 1.8-2.8 mm long.

Melilotus indicus (L.) All. var. tommasinii (Jord.)O. E. Schulz, Bot. Jahrb. Syst. 29:714. (1901).

Basionym: Melilotus tommasinii Jord., Mém. Acad. Roy. Sci. Lyon. Sect. Sci., ser.2, 1: 266 (1851)

M. indicus var. tommasinii differ from var. indicus in stem by having up to $50 \mathrm{~cm}$, stem cylindrical in lower part and cylindrical with ridges in upper part, Leaves up to $3 \mathrm{~cm}$ long. Leaflets with red veins, entire-dentate margins. Calyx 1.4-1.6 mm long, corolla $3 \mathrm{~mm}$ long; androecium up to $2.5 \mathrm{~mm}$ long; gynoecium 1.8-2.8 mm long, ovary elliptic. 


\section{Taxonomic revision of Melilotus indicus complex in Egypt}

Table (1): Comparison of morphological characters of Melilotus indicus varieties.

\begin{tabular}{|c|c|c|c|c|c|}
\hline \multicolumn{3}{|c|}{ Characters/ Taxa } & var. indicus & var. bonplandii & var. tommasinii \\
\hline \multicolumn{3}{|l|}{ Habit } & Annual--erect & Annual-procumbent, & Annual-procumbent \\
\hline \multicolumn{3}{|l|}{ Length } & Up to $30 \mathrm{~cm}$ & Up to $20 \mathrm{~cm}$ & Up to $50 \mathrm{~cm}$ \\
\hline \multicolumn{3}{|l|}{ Stem outline } & Cylindrical with ridges & Cylindrical & $\begin{array}{l}\text { Lower cylindrical upper with } \\
\text { ridges }\end{array}$ \\
\hline \multirow[t]{5}{*}{ Leaves } & \multicolumn{2}{|l|}{ Length } & $2.5-5 \mathrm{~cm}$ & $2-3 \mathrm{~cm}$ & $2-3 \mathrm{~cm}$ \\
\hline & \multirow[t]{4}{*}{ Leaflets } & Shape & $\begin{array}{l}\text { Elliptic with } \text { green } \\
\text { veins }\end{array}$ & Obovate elliptic with red veins & Elliptic with green veins \\
\hline & & Margin & Serrate-ciliate & Entire - dentate & Serrate-ciliate \\
\hline & & Apex & Truncated -acute ape & Truncate & Truncate - acute \\
\hline & & Hairs & Sparsely hairy & $\begin{array}{l}\text { Dorsal side more hairy than anterior } \\
\text { one }\end{array}$ & $\begin{array}{l}\text { Sparsely hairy with tufts at lamina } \\
\text { base }\end{array}$ \\
\hline \multirow[t]{3}{*}{ Stipule } & \multicolumn{2}{|l|}{ Shape } & Ovate & Ovate & Ovate \\
\hline & \multicolumn{2}{|l|}{ Apex } & Acuminate & Acute & Acute-acuminate \\
\hline & \multicolumn{2}{|l|}{ Hairness } & Sparsely hairy & Sparsely with tufts inside & Sparsely hairy \\
\hline \multicolumn{3}{|c|}{ No of flowers/ inflorescence } & $20-25$ & $22-25$ & $30-35$ \\
\hline \multirow[t]{3}{*}{ Calyx } & \multicolumn{2}{|l|}{ Length } & $2-2.2 \mathrm{~mm}$ & Up to $3 \mathrm{~mm} \mathrm{l}$. & $3-3.5 \mathrm{~mm}$ \\
\hline & \multicolumn{2}{|l|}{ Tube } & $0.9-1.1 \mathrm{~mm}$ & $0.8-1 \mathrm{~mm}$ & $0.9-1 \mathrm{~mm}$ \\
\hline & \multicolumn{2}{|l|}{ Teeth } & $0.2-0.3 \mathrm{~mm}$ & $0.4-0.6 \mathrm{~mm}$ & $0.9-1 \mathrm{~mm}$ \\
\hline \multirow{6}{*}{ Corolla } & \multicolumn{2}{|c|}{ Colour } & Yellow & yellow & Yellow \\
\hline & \multirow[t]{3}{*}{ Standard } & Shape & Elliptic & Elliptic & Elliptic \\
\hline & & Length & $2-2.2 \mathrm{~mm}$ & Up to $3 \mathrm{~mm}$ & $2.5-3.5 \mathrm{~mm}$ \\
\hline & & Apex & Emarginate & Obtuse & Emarginate \\
\hline & Wings & Length & $1.8-2 \mathrm{~mm}$ & $2.5-2.8 \mathrm{~mm}$ & $3.2-3.5 \mathrm{~mm}$ \\
\hline & Keel & Length & $1.8-2 \mathrm{~mm}$ & $2.6-2.8 \mathrm{~mm}$ & $3-3.2 \mathrm{~mm}$ \\
\hline \multirow[t]{2}{*}{ Androecium } & \multicolumn{2}{|l|}{ Filament } & $0.9-1 \mathrm{~mm}$ & $1.2-1.5 \mathrm{~mm}$ & $1.5-1.7 \mathrm{~mm}$ \\
\hline & \multicolumn{2}{|l|}{ Anther } & $0.6 \mathrm{~mm}$ & $0.8-1 \mathrm{~mm}$ & $0.7-0.9 \mathrm{~mm}$ \\
\hline \multirow[t]{3}{*}{ Gynoecium } & \multirow[t]{2}{*}{ Ovary } & Length & & $0.6-1.1 \mathrm{~mm} \mathrm{l}$. & $1.5-1.8 \mathrm{~mm}$ \\
\hline & & Shape & Oblong & Ellipsoid & Oblong-papillae \\
\hline & \multicolumn{2}{|c|}{ Style+ stigma } & $1 \mathrm{~mm}$ & $1-1.4 \mathrm{~mm}$ & $1 \mathrm{~mm}$ \\
\hline \multirow{3}{*}{ Pod } & \multicolumn{2}{|l|}{ Colour } & Brown & Brown & Brown \\
\hline & \multicolumn{2}{|l|}{ Shape } & $\begin{array}{l}\text { Obovate with } \\
\text { reticulate ridges }\end{array}$ & Obovate with reticulate ridges & Obovate with reticulate ridges \\
\hline & \multicolumn{2}{|l|}{ Diameter } & $3.2 \times 1.8 \mathrm{~mm}$ & $3-3.5 \times 2 \mathrm{~mm}$ & $3.5-4 \times 2.5 \mathrm{~mm}$ \\
\hline \multirow[t]{2}{*}{ Seed } & Diameter & & $1.8-2 \times 1.5 \mathrm{~mm}$ & $2-2.5 \times 1.5 \mathrm{~mm}$ & $2.5-3.5 \times 2.2 \mathrm{~mm}$ \\
\hline & Colour & & Brown & Brown & Brown \\
\hline
\end{tabular}




\section{Faiza A. Shehata}

\section{Embryo studies: (Fig.1)}

Cotyledons yellow to pale brown in the studied varieties except in var. indicus (Fig.1a); it is brown, cotyledons oblong, radical accumbant, cylindrical in var. indicus, conical in the other two varieties; radical with mucilage attached to testa in the three studied varieties
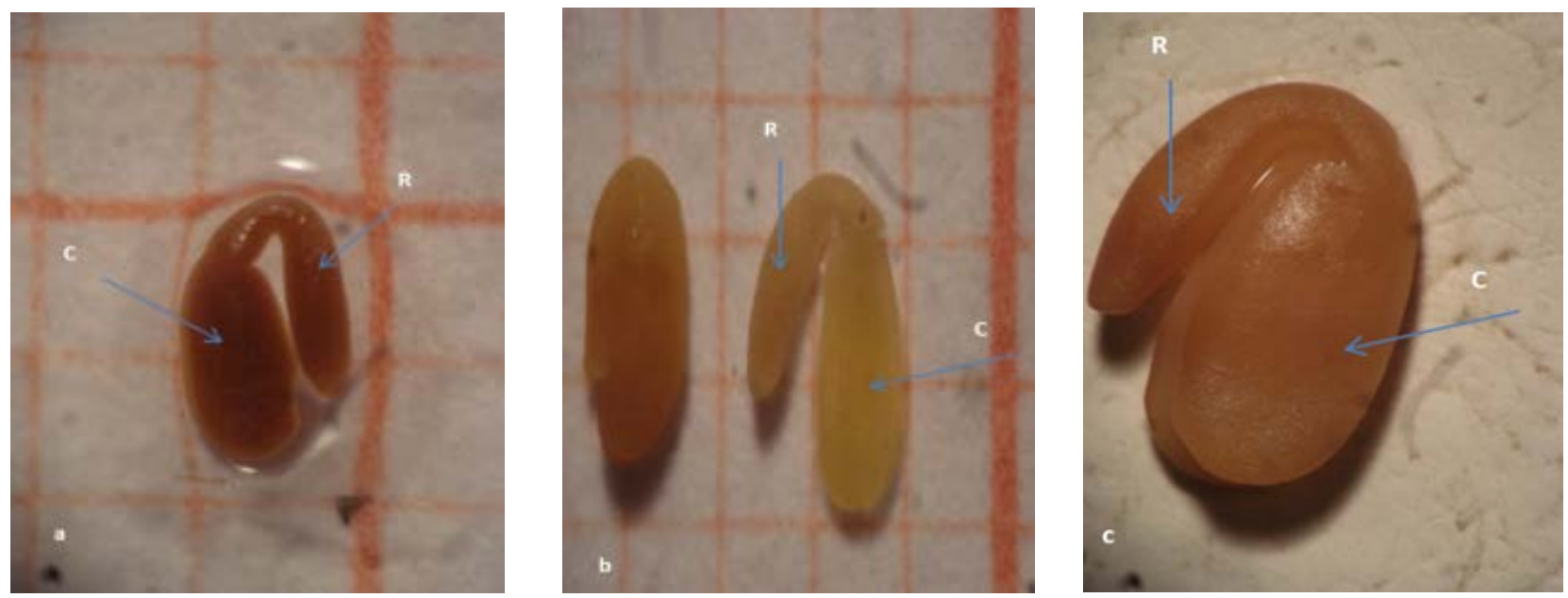

Figure I: Cotyledons and radical shape and colour of Melilotus indicus varieties: a. var. indicus, b. var. bonplandii, b. var. tommasinii. ; R. Radicle, C. Cotyledons.

Anatomical studies: (Table 2, Fig. II)

Stuessy (1990) stated that the anatomical data have been used at all levels of taxonomic hierarchy as well as for identification and assessment of taxonomic relationships among the taxa of flowering plants.

Zaki et al. (1991) proved that the characters of the cortical and vascular cylinder in stem anatomy provide a reliable character for distinction of the different species. In the present study, the outline of stem is polygonal in all the studied varieties. Epidermal cells were radially elongated in var. indicus (Fig. II, a,b) tangentially elongated in var. bonplandii (Fig. IIc,d) and tangentially elongated-radially in var. tommasinii,(Fig. II ,e,f); cell width were $15-20(30) \mu \mathrm{m}$ in all the studied varieties. Cortex consists of collenchyma followed by parenchyma. Collenchyma represented by 2-3 layers, radially elongated in var. indicus, 2-3 layers, tangentially elongated var. bonplandii and 1-2 layers at angles only, isodiametrictangentially elongated in var. tommasinii. The number of collenchyma layers were found useful in the delimitation of the studied taxa , this result coincide with the study of Shaheen (2007) who stated that the number of collenchyma layers and position, which is of taxonomic importance among the studied species of Caesalpinoideae (Fabaceae). Parenchyma 2-4 layers, tangentially elongated in all varieties. Phloem fiber is in the form of sclerenchymatous patches facing vascular bundles; (2) 4-6 layers in all the studied varieties. Bundle sheath well defined, tangentially elongated cells; a layer of tubular cells circles the bundle. The number of vascular bundles was found significance in the studied taxa; it was 18-20 in var. indicus and var. bonplandii while 13-14 in var. tommasinii. Phloem up to 4 layers, $12-18 \mu \mathrm{m}$ wide, cambium 1-2 layers, up to $5 \mu \mathrm{m}$ wide, Xylem arches 3-6 (7), vessels 4-7 (8) per arch in all the studied varieties. Pith cells isodiametric in var. indicus, isodiametric - tangentially elongated in var. bonplandii and was partially hollow in var. tommasinii. 


\section{Taxonomic revision of Melilotus indicus complex in Egypt}
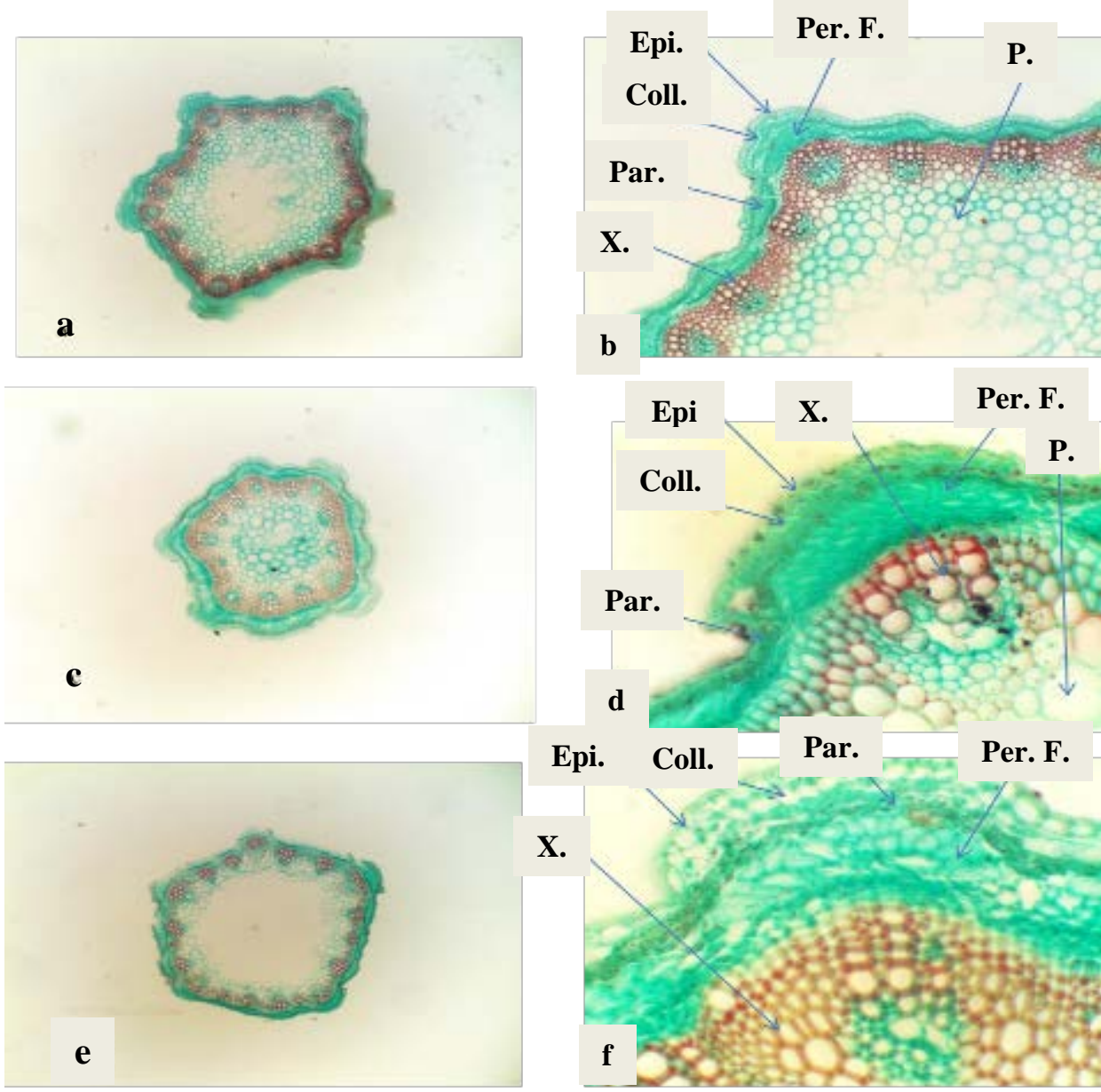

Figure II. Anatomical studies of stems of Melilotus indicus: a, b. var. indicus; c, d, var. bonplandii; e, f, var. tommasinii. Epi.; epidermis, Coll.; collenchyma, Par.; Parenchyma, Per. F.; pericyclic fibers, X.; xylem., P; pith

Table (2): Anatomical characters of stem in Melilotus indicus varieties.

\begin{tabular}{|c|c|c|c|c|c|}
\hline \multicolumn{3}{|c|}{ Characters } & var. indicus & var. bonplandii & var. tommasinii \\
\hline \multicolumn{3}{|l|}{ Outline } & Polygonal(5-6-ogonal ) & Pentagonal & Pentagonal \\
\hline \multicolumn{3}{|c|}{ Diameter mm } & $1.6-1.7$ & $1.4-16$ & $1.2-1.3$ \\
\hline \multirow{2}{*}{\multicolumn{2}{|c|}{ Epidermal cell }} & Shape & Radially elongated & Tangentially elongated & $\begin{array}{l}\text { Tangentially } \\
\text { elongated-radially } \\
\text { elongated at angles }\end{array}$ \\
\hline & & Width $\mu \mathrm{m}$ & $15-20$ & $20-30$ & $17-20$ \\
\hline \multirow[t]{6}{*}{ Cortex } & \multirow[t]{3}{*}{ Collenchyma } & Number of layers & $2-3$ & $2-3$ & $1-2$ at angles only \\
\hline & & Cell shape & Radially elongated & Tangentially elongated & $\begin{array}{l}\text { Isodiametric- } \\
\text { tangentially elongated }\end{array}$ \\
\hline & & Width $\mu \mathrm{m}$ & $35-50$ & $30-40$ & $20-25$ \\
\hline & \multirow[t]{3}{*}{ Parenchyma } & Number of layers & $3-4$ & $2-3$ & $2-3$ \\
\hline & & Cell shape & Tangentially elongated & Tangentially elongated & Tangentially elongated \\
\hline & & Width $\mu \mathrm{m}$ & $40-55$ & $12-20$ & $30-40$ \\
\hline \multirow{2}{*}{\multicolumn{2}{|c|}{ Vascular bundles }} & Number & $18-20$ & $13-14$ & $18-20$ \\
\hline & & Width $\mu \mathrm{m}$ & $260-270$ & $150-165$ & $170-185$ \\
\hline \multirow{2}{*}{\multicolumn{2}{|c|}{ phloem fiber }} & Number of layers & $4-6$ & $2-4$ & $4-5$ \\
\hline & & Width $\mu \mathrm{m}$ & $25-30$ & $20-30$ & $40-50$ \\
\hline \multirow{2}{*}{\multicolumn{2}{|c|}{ Phloem }} & Number of layers & $3-4$ & $2-3$ & $3-4$ \\
\hline & & Width $\mu \mathrm{m}$ & $12-18$ & $5-10$ & $20-25$ \\
\hline \multirow{2}{*}{\multicolumn{2}{|c|}{ Cambium }} & Number of layers & $1-2$ & $1-2$ & $1-2$ \\
\hline & & Width $\mu \mathrm{m}$ & $2-4$ & $2-5$ & $3-5$ \\
\hline \multirow{3}{*}{\multicolumn{2}{|c|}{ Xylem }} & Number of arches & $3-6$ & 3-7 & $3-5$ \\
\hline & & Number of vessels & $4-7$ & $3-6$ & $3-8$ \\
\hline & & Width $\mu \mathrm{m}$ & $160-175$ & $100-115$ & $100-120$ \\
\hline \multirow{2}{*}{\multicolumn{2}{|c|}{ Pith }} & Cell shape & Isodiametric & $\begin{array}{l}\text { Isodiametric-radially } \\
\text { elongated }\end{array}$ & Isodiametric \\
\hline & & Diameter $\mu \mathrm{m}$ & $750-775$ & $900-950$ & $500-600$ \\
\hline
\end{tabular}




\section{Faiza A. Shehata}

Seed studies (Table 3, Fig. III)

\section{Seed Morphology and Spermoderm}

Many of the seed identifications have recently been based upon morphological characteristics including seed size, general appearance, outer shape and hilum length etc.; seeds of family Fabaceae were much useful for classification and of taxa at different levels (Gunn. 1981; Capitaine 1912). Seed coat pattern or the micro ornamentation on the surface of the outer cell wall can be considered of taxonomic significance (Barthlott 1981, Gupta 1991, Small et al.1990, Husain et al. 1994, Abou Sbaih et al.1994, Taia 2004, Salimpour et al. 2007, Pinaretal.2009, Abid et al. 2018).

In the present study the general shape of the seeds in the three taxa were prolate- spheriodal with rounded poles, brown with longitudinally subapical hilum (Fig.3, c,h,m). Seed length 1-1.4 $\mu \mathrm{m}$ in the three varieties. Length/width ratio up to 1-1.3 in both var. indicus and var. tommasinii (Fig.3, k) while it was up to 1.87 in var. bonplandii (Fig.3f). Seed coat pattern rugose-tuberculate in var. indicus (Fig.3e), verrucate with irregular surface in the other two varieties. Outline of cells polygonal, isodiametric-irregular in the studied taxa. Anticlinal wall lobbed in var. indicus and var. tommasinii while Sinuate in var. bonplandii. Relief of cell boundary raised in var. indicus, channeled in in the other varieties. Curvature of outer periclinal wall convex in var. indicus and var. bonplandii while concave in var. tommasinii (Fig. 3, e,j,o respectively).

Table (3): Comparison of size, shape, spermoderm and hilum features in examined Melilotus indicus varieties.

\begin{tabular}{|c|c|c|c|c|}
\hline \multicolumn{2}{|c|}{ CharacterlSpecies } & \multirow{2}{*}{$\begin{array}{l}\text { var. indicus } \\
0.93 \times 0.7\end{array}$} & \multirow{2}{*}{$\begin{array}{l}\text { var. bonplandii } \\
1.367 \times 0.7\end{array}$} & \multirow{2}{*}{$\begin{array}{l}\text { var. tommasinii } \\
1.07 \times 0.933\end{array}$} \\
\hline Seed size & "LXW mm & & & \\
\hline & " $\mathrm{L} \backslash \mathrm{W}$ ratio & 1.3 & 1.87 & 1.14 \\
\hline \multicolumn{2}{|l|}{ Seed poles } & Rounded & Rounded & Rounded \\
\hline \multicolumn{2}{|l|}{ Seed shape } & Subprolate & Prolate & Prolate-spheriodal \\
\hline \multicolumn{2}{|c|}{ Seed coat pattern } & Rugose-tuberculate & Verrucate with irregular surface & Verrucate with irregular surface \\
\hline \multirow[t]{3}{*}{ Hilum } & Position & Subapical & Subapical & Subapical \\
\hline & Shape & $\begin{array}{l}\text { Longitudinally } \\
\text { Elliptic }\end{array}$ & $\begin{array}{l}\text { Longitudinally } \\
\text { Elliptic }\end{array}$ & $\begin{array}{l}\text { Longitudinally } \\
\text { Elliptic }\end{array}$ \\
\hline & Size $\mu \mathrm{m}$ & $68 \times 68$ & $68 x 73$ & $68 \times 73$ \\
\hline \multicolumn{2}{|c|}{ Outline of cells } & Polygonal, elongated-irregular & Polygonal & Isodiametric-polygonal \\
\hline \multicolumn{2}{|c|}{ Anticlinal wall } & Lobbed & Sinuate & Lobbed \\
\hline \multicolumn{2}{|c|}{ Relief of cell boundary } & Raised & Channeled & Channeled \\
\hline \multicolumn{2}{|c|}{ Thickness of cell boundary } & Thick & Thick & Moderate \\
\hline \multicolumn{2}{|c|}{$\begin{array}{l}\text { Curvature of outer periclinal } \\
\text { wall }\end{array}$} & Convex & Convex & Concave \\
\hline
\end{tabular}




\section{Taxonomic revision of Melilotus indicus complex in Egypt}
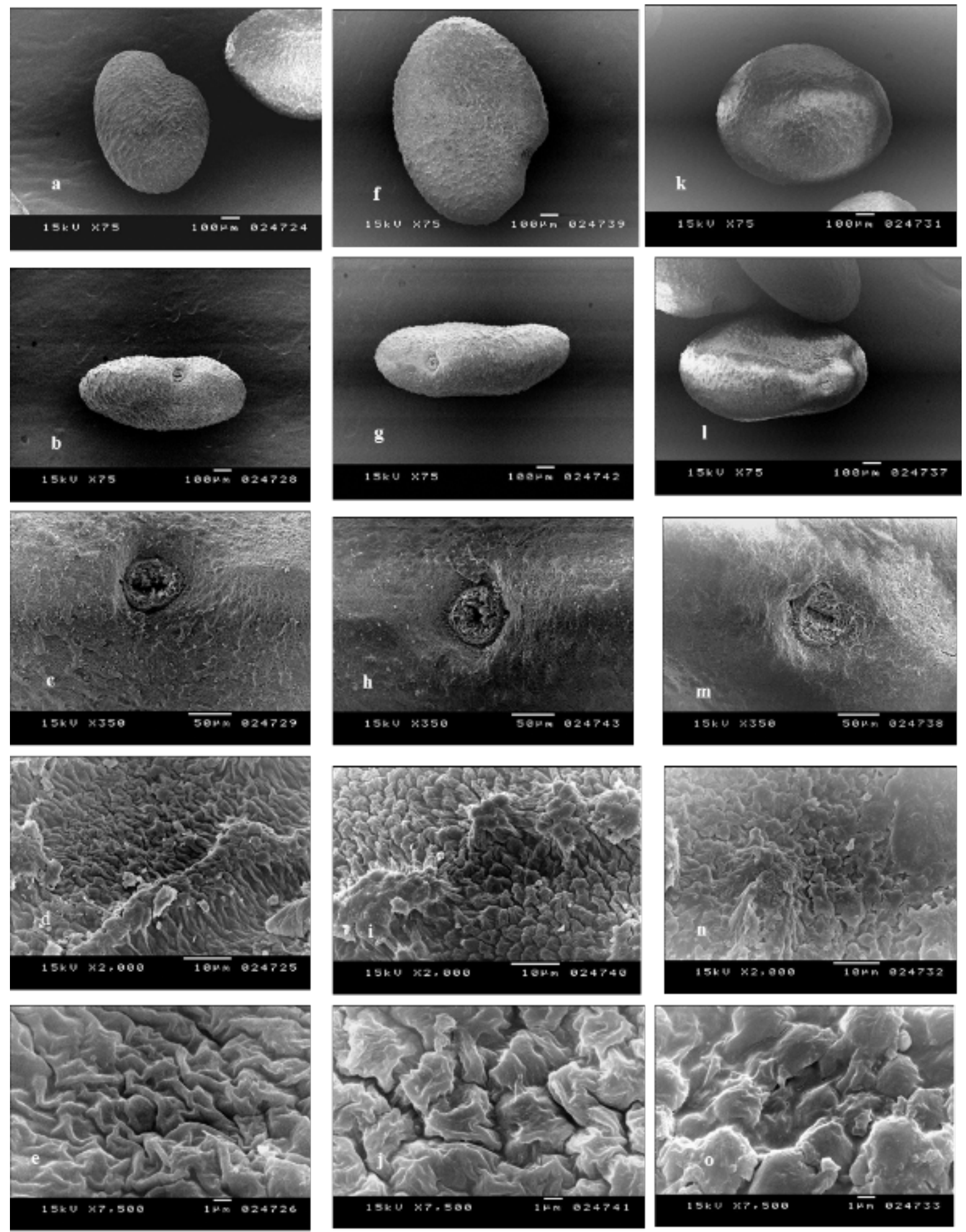

Figure III: Seed morphology and Spermoderm under SEM of Melilotus indicus varieties: a-e; var. indicus, f-j; var. bonplandii, k-o; var. tommasinii a, ,f, ,k; Seed b, g, I;. Hilum position. c, h, m; Hilum shape d,I,n,e,j,o. Seed spermoderm.

\section{Spermoderm anatomy (Fig. VI, Table 4).}

Testa of examined taxa consists of four layers; exotesta which consists of thick elongated cells (macrosclereids) coated externally by cuticle. The second layer is light line (linea lucida), after Peske \& Pereira (1983), Desouza \& Marsos-Filho (2001), the third layer forms hourglass cells and the fourth layer is interior parenchyma. Radicle shape cylindrical in var. indicus, ovate in the other varieties. 


\section{Faiza A. Shehata}

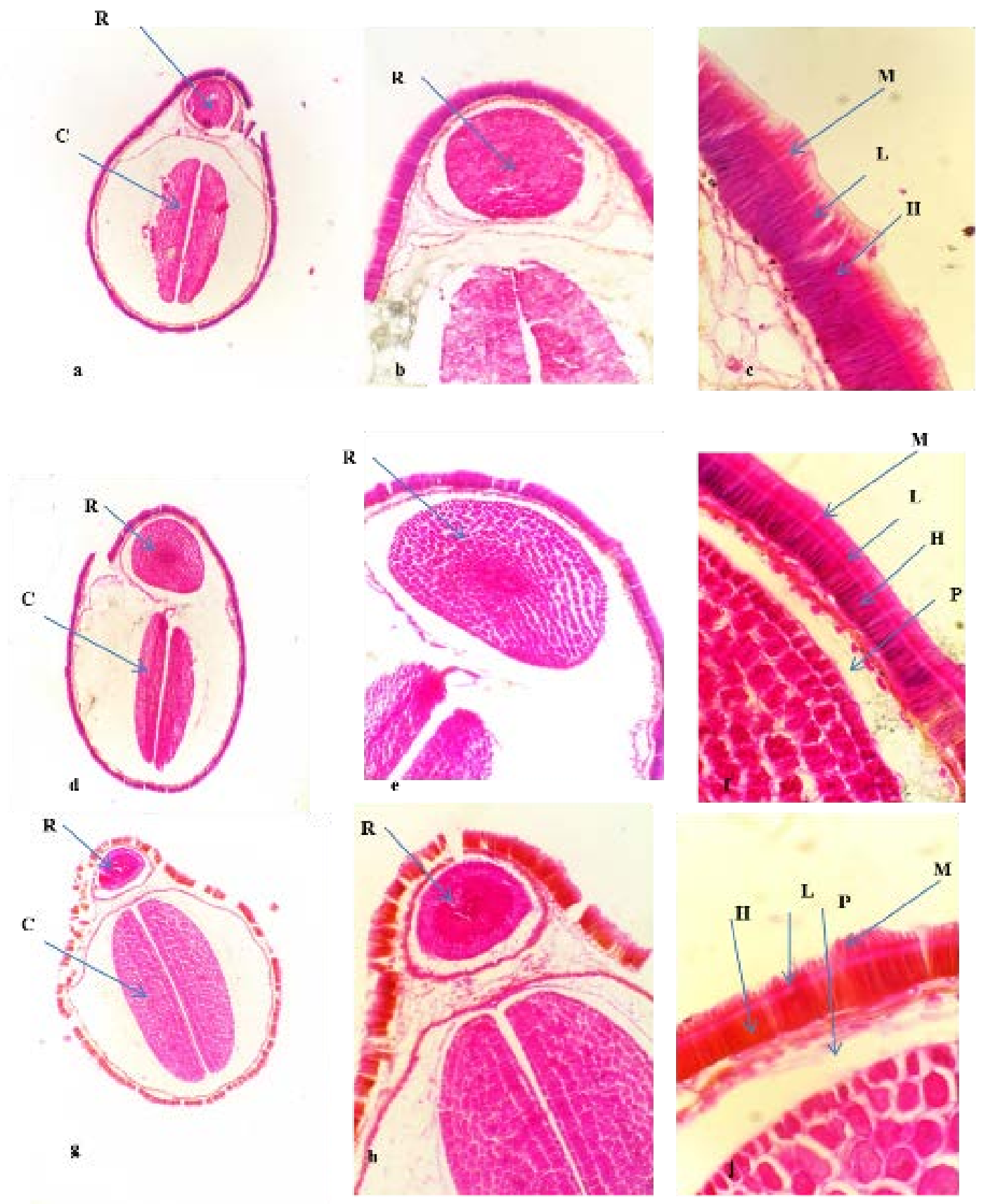

Figure IV: Speroderm anatomy as seen under LM of Melilotus indicus varieties: a,b,c; var indicus, d, e, f; var. bonplandii. g, h, i; var. tommasinii. a. L.S. in seed, b. Radicle shape, c. Testa: R, Radicle, C, Cotyledons, M. Macrosclereids, L. Linea lucida, H. Hourglass cells, P. Parenchyma.

Table (4): Comparison of spermoderm anatomy of $M$. indicus varieties.

\begin{tabular}{|l|l|l|l|l|}
\hline Characters/ Species & var. indicus & var. bonplandii & var. tommasinii \\
\hline \multicolumn{2}{|l|}{ Cuticle Thickness $\mu \mathrm{m}$} & 9 & 9 & 9 \\
\hline \multirow{2}{*}{$\begin{array}{l}\text { Exotesta } \\
\text { Macrosclereid }\end{array}$} & Thickness $\mu \mathrm{m}$ & $12-15$ & $12-15$ & $12-15$ \\
\cline { 2 - 5 } & No. of layers & 1 & 1 & 1 \\
\hline Light Layer Thickness $\mu \mathrm{m}$ & $3-4$ & $3-5$ & $3-5$ \\
\hline Hourglass Layer Thickness $\mu \mathrm{m}$ & $37-45$ & $30-35$ & $35-37$ \\
\hline Protein Layer $\mu \mathrm{m}$ & $7-8$ & $7-8$ & $7-8$ \\
\hline \multirow{2}{*}{ Radical } & Diameter $\mu \mathrm{m}$ & $350-400 \times 450-500$ & $450-500 \times 300-350$ & $270-290 \times 380-400$ \\
\cline { 2 - 5 } & Shape & Cylindrical & Ovate & Ovate \\
\hline \multirow{2}{*}{ Cotyledons } & Length $\mu \mathrm{m}$ & $300-375$ & $275-290$ & $325-340$ \\
\cline { 2 - 5 } & L c/L s ${ }^{*}$ ratio & 0.57 & 0.61 & 0.61 \\
\cline { 2 - 5 } & Welws & 0.38 & 0.31 & 0.48 \\
\hline
\end{tabular}

${ }^{*} \mathrm{~L}$ c/L s: length of cotyledons /length of seed

*Wclws: width of cotyledons /width of seed 


\section{Taxonomic revision of Melilotus indicus complex in Egypt}

In conclusion, the grouping of different varieties based on seed spermoderm, embryonic features and anatomical characters correlated well with gross morphology.

\section{Acknowledgment}

My grateful thanks to Prof Zaki A. Turki, Professor of Taxonomy \& Flora, Botany and Microbiology Department, Faculty of Science, Menufia University, for his revision and helpful comments that improved the manuscript.

\section{References}

Abou-El-Enain, M. M. and Loutfy, M. H. 1999. SEM of seed coat surface characters and the taxonomic relationships in the genus Sesbania Scop. (LeguminosaePapilionoideae). Taeckholmia 19: 53-61.

Abou-El-Enain, M., Loufty, M. and Shehata, A. 2007. Seed surface characters and their systematic significance in the genus Lathyrus (Leguminosae, Papilionoideae, Vicieae). Feddes Repertorium 118: 269-285.

Abd El Gawad, M. A., Salem, M. O. and Hegazi, A. M., 1989. Anatomy of Alfalfa leaflets as affected by N P K-fertilization and saline irrigation. Ann., Agri. Sci. Moshtohor; 27(3):1539-1447.

Abd El Rahman, A. A., Amal, A. Ibrahim, Hassan, H. A. 1976. Contribution to anatomical characters of some xerophytes. Bull. Fac. Sci. Cairo Uni. 49: 26-45.

Abid, R., Ali, S. A., Saeed, E., Munir, I., Hashemi, S. U., Ather, A., Qaiser, M. 2108. Chemotaxonomy and seed morphological studies of the genus Melilotus Mill. from Pakistan. Pak. J. Bot. 50(2): 575-578

Abou Sbaih, H. A., and Jury, S. L., 1994. Seed micromorphology and taxonomy in Orobanche (Orobanchaceae), Fl. Medit. 4: 4148.

Barthlott, W. 1981: Epidermal and seed surface characters of plants: Systematic applicability and some evolutionary aspects. Nordic J. Bot., 1:345-355.

Barthlott, W. 1984: Microstructural Features of Seed Surfaces. In: Current Concepts in Heywood, V.H. and D.M. Moore (eds.). Plant Taxonomy. Pp. 95-104 Academic Press, London.

Boulos, L., 1995: Flora of Egypt Checklist. Al Hadara Publishing, Cairo.

Boulos, L., 1999: Flora of Egypt. Vol.1. Al Hadara Publishing, Cairo.

Boulos, L., 2009: Flora of Egypt Checklist, Revised annotated edition. Al Hadara Publishing, Cairo.
Capitaine, L., 1912: Les graines des Légumineuses. Paris, Larose-Lechevalier.

Christenhusz, M. J. and Byng, J. W. 2016. The number of known plants species in the world and its annual increase. Phytotaxa 261(3): 201-217.

Corner, E. J. H. 1976. The Seeds of Dicotyledons. Vol. I. Cambridge University Press, Cambridge, New York.

Desouza, F. H. D. and Marcos-Filho, J. 2001. The seed coat as a modulator of seed environment relationships in Fabaceae. Revta brasil. Bot. 24: 365-35.

Duke, J. A. and Polhill, R. M. 1981. Seedlings of Leguminosae. In RM Polhill \& $\mathrm{PH}$ Raven (eds.). Advances in Legume Systematics. Part 1. Royal Botanic Gardens, Kew.

El Hadidi, M. N. and Fayed, A. A. 1994/95. Material for Excursion Flora of Egypt Taeckholmia 15: 1-223, pp. 57-76.

El Karemy, Z. and Hosni, H. A. 1999. Systematic revision on Leguminosae in Egypt, 2. Lathyrus L., Flora Mediterranea 6:31-42.

Gazara, M., Kamel, W. and Haider, A. 200. Cladistic analysis of the genera: Trifolium, Trigonella and Melilotus (Fabaceae: Papilionaceae) in Egypt. Egypt J. of Biol. 3:161-170.

Gunn, C.R. 1972. Seed Characteristic. In: Alfalfa Science and Technology. American Society of Agronomy, Madison, Wisconsin.

Gunn, C.R., 1982. Seed topography in the Fabaceae. Seed Sci. Technol., 9:737-757.

Gupta, M. 1977: Vascular anatomy of the flower of Melilotus, Papilionaceae. Plant Sci. 9:31-36.

Gupta, M. 1991: Seed coat structure in some species of Trigonella- Scanning Microsc., 5(3):787-796.

Hosni, H. A. and Karemy, Z. 1993. Systematic revision of Leguminosae in Egypt, I. Tephrosia Pers. Sendtnera 1: 245-257.

Husain, S. Z., Aziz, K., Syeda, S. T. and Jahan, N. 1994. Micromorphological studies 
of seven species of the genus Medicago L., (Fabaceae) from Pakistan. Pak. J. Bot. 26(2): 409-419.

Ignacimuthu, S. and Babu, C.R. 1985. Significance of seed coat pattern in Vigna radiata var. sublobatus. Proc Indian Acad Sci. 94:561-566.

Johansen, D. A. 1940. Plant microtechnique. McGraw-Hill Book Co., New York, N.Y.

Khandani, S., Assadi, M., Nejadsatar, I. T. and Mehregan, I. 2016. Phenetic analysis of the genera medicagoid Trigonella, Medicago and Melilotus (Fabaceae) on seed coat in Iran. Biodiversitas 17(1): 162-171.

Lashin, G. M. A. 2006. Comparative Morphology of Pollen Grains of Some Taxa of Tribe Trifolieae (Fabaceae: Papilionoideae) from Egypt. Int. J. Bot. 2(3): 270-277.

Lersten N. R. 1981. Testa topography in Leguminoseae subfamily Papilionoideae. Proc. Iowa Acad. Sci. 88:180-191.

Mcmurry, B. E. and Fisk, E. L. 1936. Vascular anatomy of the seedling of Melilotus alba. Bot. Gaz. 98(1):121-13.

Mirzaei, L., Assadi, M., Nejadsatari, T. and Mehregan, I. 2015. .Comparative seed and leaf micromorphology of Colutea species (Fabaceae) from Iran. Environ. Exp. Biol. 13: 183-187.

Morton, Fr. 1915: Pflanzengeographische Monographieder Inselgruppe Arbe, umfassend die Inseln Arbe, Dolin, S. Gregorio, Goli und Pervicchiosamt den umliegenden Scoglien.In Engler A., Botanische Jahrbiiche für Systematik, Pflanzengeschichte und Pflanzengeographie. Verlag von Wilhelm Engelmann.

Norbert, L. and Jonitz, A. 2009: Identification of seeds to genus and species level, ISTA Purity Seminar, Zürich.

Nyola, U. and Sharma, K.C. 2009 .Taxonomic significance of seed coat structure and spermoderm patterns in four species of vigna (Fabaceae). J. Phytol. Res. 22:37-42.

Özbek, F., Özbek, M. U. and Ekici, M. 2014. Morphological, anatomical, pollen and seed morphological properties of Melilotus bicolor Boiss. \&Balansa (Fabaceae) endemic to Turkey. Australian Journal of crop Science 8(4): 543-549.
Pandey, B. P. 1982: Plant Anatomy- New Delhi.

Peske, S. T. and Pereira, L. A. G. 1983. Tegumento da semente de soja. Tecnologia de sementes 6: 23-34.

Pınar, N. M., Duran, A., Eter, T. and Tuğ, G. N. 2009. Pollen and seed morphology of the genus Hesperis L. (Brassicaceae) in Turkey. Turk. J. Bot. 33: 83-96.

Salimpour, F., Mostafavi, G. and Sharifnia, F. 2007. Mircromorphological Study of the Genus Trifolium Section Lotoidea, in Iran, Pakistan Journal of Biological Science, 10(3): 378-382.

Sass, J. E. 1961. Botanical Microtechnique, $3^{\text {rd }}$ ed. - Amsterdam.

Schulz, O. E. 1901. Monographie der GattungMelilotus. In Engler A., Botanische Jahrbücher fur Systematik, Pflanzengeschichte und Pflanzengeographie. Verlag von Wilhelm Engelmann, Leipzig. 29: 660-735.

Shaheen, A. S. M. 2007. Characteristics of the stem - leaf transitional zone in some species of Caesalpinioideae (Leguminosae). Turkish Journal of Botany, 31: 297-310.

Small, E. and Brookes, B. S.1990. A taxonomic simplification of Medicago italica. Canadian Journal of Botany 68: 21032111.

Stearn, W. T. 1992. Botanical Latin, $4^{\text {th }}$ ed. Timber Press, Oregon, USA.

Stuessy, F. T. 1990. Plant taxonomy, the systematic Evolution of comparative Data. Columbia University Presses. New York.

Täckholm, V. 1974. Students' Flora of Egypt. ed. 2, Cairo University, Egypt. 888pp.

Taia, W. K. 2004: Tribe Trifolieae: Evidence from seed characters. Pak. J. Biol. Sci. 7(7):1287-1302.

Werker, E. 1997. Seed anatomy. Berlin \& Stuttgart: Borntra"ger Verlag.

Weber, W. A. 1985. The genus Teloxys (Chenopodiaceae). Phytologia 58: 477-478

Zaki, M. A., Hosni, H. A. and Araffa, S. 1991. Morphological and anatomical features of species Tamarix in Egypt. - J. Appl. Sci. 6(10): 502-511.

Zareh, M., Farid, H. and Farghaly, N. 2017. Micromorphological studies on the genus Lotus L. (Fabaceae: Loteae) from Egypt. Turk. J, Bot. 41: 273-288. 